were widely used for mild hypertension in the $1960 \mathrm{~s}$ and ' $70 \mathrm{~s}$ might have done more harm than good, ${ }^{3+2}$ and this mistake may be potentially repeated in subjects with hypercholesterolaemia.

Doubts are even stronger in women: firstly, the effect of cholesterol lowering remains to be shown and, secondly, the incidence of coronary heart disease is already very low in middle aged women.

Further studies of the long term effects of individual intervention on both biological processes and quality of life are needed, especially for women and other low risk groups. In the mean time it is prudent to recall that a high serum cholesterol concentration is caused by unhealthy eating habits. Our analysis above indicates that individual interventions should be implemented with great caution. The widely recommended intervention limits ${ }^{560}$ should be adjusted to include only a small proportion of the population. To what extent women should be included in such programmes is unclear. The use of drugs should be reserved for subjects with genetic hypercholesterolaemia or those who are otherwise at very high risk of arteriosclerotic disease.

We thank Anne Brit Westerheim, Per Maehlumshagen, and Gavin Mooney for their valuable contributions.

\footnotetext{
1 Hjermann I, Holme I, Leren P. Effect of diet and smoking intervention on the incidence of CHD. Lancet 1981;ii:1303-10.

2 incidence of CHD. Lancet 1981;11:1303-10. Reduction in incidence of coronary heart disease. F..11.4 1984:251:351-64. The Lipid Research Clinics Coronary Primary Prevention Trial results. II The Lipid Research Clinics Coronary Primary Prevention Trial results. II
The relationship of reduction in incidence of coronary heart disease to The relationship of reduction in incidence of
cholesterol lowering. F $A M A$ 1984;251:365-74.

cholesterol lowering. 7 AMA 1984:251:365-74.
+ Frick MH, Elo O, Haapa K, Heinonen OP, Heinsalmi P, Helo P. Helsinki heart study: primary prevention trial with gemfibrozil in middle-aged men with dyslipidemia. N Engl f Med 1987;317:1237-45

5 Bjartveit $\mathrm{K}$, Blomhoff JP, Drevon CA, et al. A cholesterol lowering programm for the adult population. Tidsskr Nor Lacgeforen 1988;108:2285-8. (In Norwegian.)

6 NCEP: Report of the national cholesterol education program expert panel on detection, evaluation, and treatment of high blood cholesterol in adults. Arch Intern Med 1988;148:36-69.

7 Weinstein MC Cost-effectiveness of interventions to prevent or treat coronary heart disease. Annu Rer Public Health 1985;6:41-63.

8 Oster G, Epstein AM. Primary prevention of coronary heart disease: the economic henefits of lowering serum cholesterol. Am f Public Health 1986:76:647-56.

9 Oster G, Epstein AM. Cost-effectiveness of antihyperlipemic therapy in the prevention of coronary heart disease. FA.MA 1987:258:2381-7.

10 Hall JP. A cost-cffectiveness analysis of alternative strategies for the prevention of heart disease. Med f A ust 1988;148:273-7.

11 Kinosian BP, Eisenberg JM. Cutting into cholesterol. FAMA 1988;259: 2249-54.
}

\section{Microvascular vasodilatation in feet of newly diagnosed non-insulin dependent diabetic patients}

\section{Diabetes Research \\ Laboratories, Postgraduate \\ Medical School, University of Exeter, Exeter EX2 5DW D D Sandeman, MRCP,} research registrar

C A Pym, RGN, research nurse E M Green, BSC, research nurse

C Seamark, MRCGP, clinical assistant

A C Shore, PHD, research fellow

$\mathrm{J}$ E Tooke, MRCP, senior

lecturer in medicine

Correspondence to:
Dr Sandeman.

BMF 1991;302:1122-3
12 Martens LI, Rutten FFH, Erkelens 1)W, Ascoop CAPL. Cost effectiveness of cholesterol-lowering therapy in the Netherlands. Am F. Med 1989;87 suppl $4 \mathrm{~A}: 5+-8$

13 Standing Medical Advisory Committee to the Secretary of State for Health. The cost-effectiveness of opportunistic cholesterol testing. London: SMAC, 1990. 4 Weinstein MC, Stason WB. Foundations of cost-effectiveness analvsis for health and medical practices. $N$ Engl 7 Med 1977;296:716-21

15 Eggen AE, Michlumshagen PM, Westerheim AB, Kristiansen IS. Economical analysis of a cholesterol lowering program. Tidsskr Nor Leceforin 1989:109: 857-63. In Norwegian

16 Wrsowski DK, Kennedy DL, (iross TP. Prescribed use of cholesterollowering drugs in the United States, 1978 through 1988. F. .1. 1990;263: 2185-8

17 Salonen JT, Puska P, Kottke TE, et al. Changes in smoking, serum cholesterol and blood pressure levels during a community-based cardiovascular disease prevention program - the North Karelia project. Am F Epidemiol 1981;114 $81-9+$

18 National Health Screening Service. The cardiovascular disease study in Norevegian counties-results from the second screening. Oslo: National Health Screening Service, 1988

19 Multiple Risk Factor Intervention Trial. Risk factor changes and mortality results. F.A.114 1982:248:1+65-77

20 Stein EA. Management of hypercholesterolemia. Am F.Med 1989;87 suppl HA : $20-27 \mathrm{~S}$.

21 W'estlund $\mathrm{K}$, Nicholaysen $\mathrm{R}$. Ten-vear mortality and morbidity related to serum cholesterol. Scand f Clin Lab Invest 1972:30 (suppl 127):3-24.

22 Central Bureau of Statistics. Causes of death 1985. Oslo: Central Bureau of Statistics, 1986.

23 Williams A. Fconomics of coronary artery hypass grafting. BMY 1985;291: 326-9.

24 Finkler SA. The distinction between cost and charges. Ann Intern Med 1982:96:102-9.

25 Slattebrekk OV. Cost per patient based on DR(j-classification. Trondheim: Norwegian Institute of Hospital Research, 1990, Report STF-81-A90003. In Norwegian.

26 Read JL, Quinn RJ, Berwick DM, Fineberg HV, Weinstein MC. Preferences for health outcomes. Med Decis. Making 1984;4:315-29.

27 Weinstein MC, Fineberg HV. Clinical decision analysis. Philadelphia: Saunders, 1980

28 Weinstein MC, Stason WB. Cost-effectiveness of coronary arterv hipass surgerv. Circulation 1982;66 (suppl III :56-66.

29 Goldman L, Sia STB, Cook EF, et al. Costs and effectiveness of routine therapy with long term beta-adrenervic antagonisss after acute myecardial infarction. Y Fingl f Med 1988:319:152-7.

30 Bloom JR, Monterossa S. Hypertension labeling and sense of well-being. A $m$ f Public Health 1981;71:1228-32.

31 Stoate HG. Can health screening damage vour health? $7 R$ Coll (ien Pract $1989 ; 39: 193-5$.

32 Goldman L, Weinstein MC, Williams LW. Relative impact of targeted versus populationwide cholesterol interventions on the incidence of coronary hear disease. Circulation 1989;80:254-60.

33 Kinley $S$, Heller RF. Effectiveness and hazards of case finding for a high cholesterol concentration. BMY 1990;300:1545-7.

34 Holme I. Drug treatment of mild hypertension to reduce the risk of (CHD): Is it worth-while? Stat Med 1988;7:1 109-20.

35 Thurmer H, Lund-Larsen PG, Tverdal A, Thelle DS. Treatment of hypertension as a risk factor in a prospective study. International fournal of Risk and Safety in Medicine 1991;1:267-78.

36 European Atherosclerosis Society. The recognition and management of hyperlipidaemia in adults: a policy statement of the European Atherosclerosis Society. Eur Heart f 1988;9:571-600.

Accepted 12 March 1991)

diabetic subjects without significant large vessel disease and compared the results with those from healthy controls and insulin dependent diabetic subjects.

\section{Patients, methods, and results}

Nine non-insulin dependent diabetic patients (assessed on clinical grounds) were recruited from successive referrals to our clinic (four women, five men, median age 42 (range 25-60) years. Controls matched for age and sex (hospital staff with no medical history, mean age 40 (25-60)) and insulin dependent diabetic patients matched for age and sex (mean age 42 (25-60), median duration of diabetes $19(2-48)$ years) were recruited for comparison. Hypertensive subjects, those taking vasoactive drugs, and those with large vessel disease (indicated by a previous vascular event, ankle systolic index $<0 \cdot 1$, or absent foot pulses) were excluded.

Brachial systolic blood pressure was higher in the insulin dependent patients than in the non-insulin dependent patients or the controls (median 144 (112$160) \mathrm{mm} \mathrm{Hg}, 126(105-170) \mathrm{mm} \mathrm{Hg}$, and 120 (106-140) $\mathrm{mm} \mathrm{Hg}$, respectively; $\mathrm{p}<0.05)$, although no difference in systolic pressure taken at the ankle or brachial diastolic pressure was found. Ambient blood glucose An impairment of this response has been shown in type I (insulin dependent) diabetes. ${ }^{2}$ We examined the integrity of this response in non-insulin dependent 


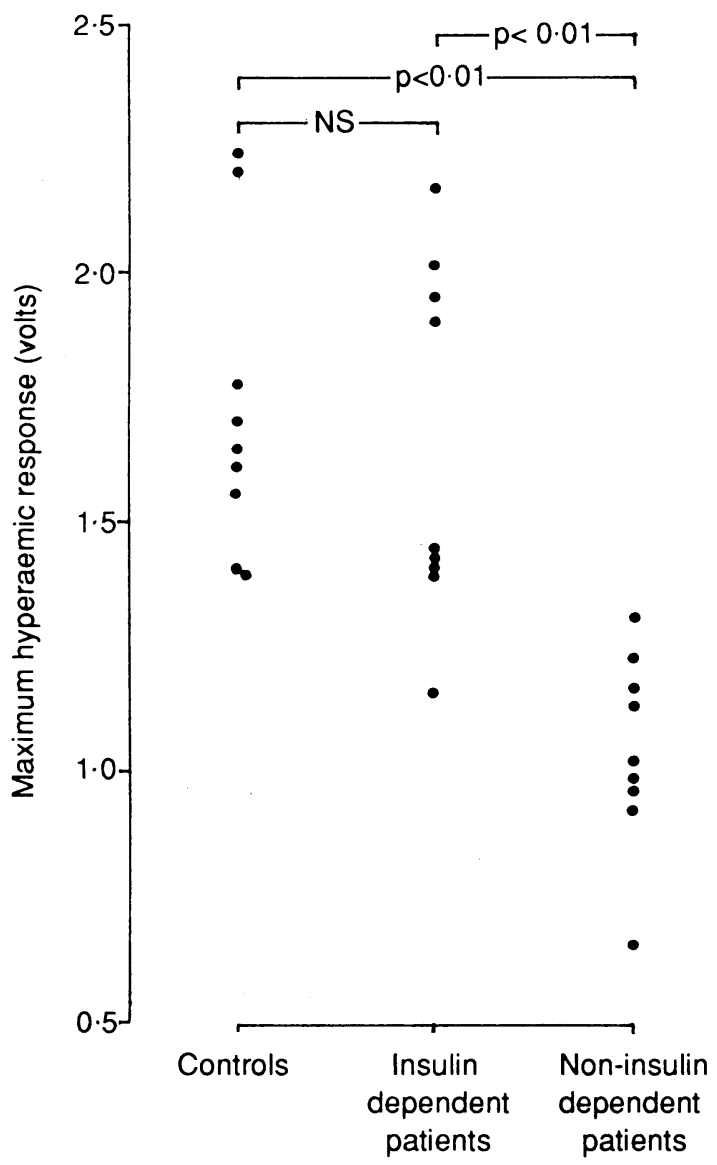

Maximum blood flow (mean values for eight sites) in feet of healthy controls, and diabetic patients

concentration was higher in the insulin dependent subjects than in the non-insulin dependent subjects during the study (median $10.5(4.7-18.3) \mathrm{mmol} / \mathrm{l}$ and $7 \cdot 8(4 \cdot 0-12 \cdot 1) \mathrm{mmol} / \mathrm{l}$ respectively; $\mathrm{p}<0 \cdot 01)(\mathrm{BM}$ test 1-44, Reflolux II meter, Boehringer Mannheim).

Studies were performed after 30 minutes' acclimatisation in a temperature controlled laboratory $(22.0$ $\left.(\operatorname{SD~} 0 \cdot 4)^{\circ} \mathrm{C}\right)$. The skin was heated with a brass heater ${ }^{2}$ to a probe temperature of $44^{\circ} \mathrm{C}$, and flow was measured in eight sites with laser Doppler fluximetry (Periflux Pf2, Perimed, Sweden). The mean of the eight readings, the maximum hyperaemic response, was arbitrarily expressed in volts $(\mathrm{V})$.

The maximum hyperaemic response was significantly impaired in the non-insulin dependent patients when compared with either the controls or insulin dependent patients (median $1.0(0.65-1.32) \mathrm{V}, 1.65$ $(1 \cdot 39-2 \cdot 24) \mathrm{V}$, and $1 \cdot 45(1 \cdot 10-2 \cdot 18) \mathrm{V}$, respectively; (figure). The $95 \%$ confidence interval (Friedman two way analysis of variance, $p=0.001$ ) for the difference between the maximum hyperaemic response in insulin dependent and non-insulin dependent patients was -0.901 to $-0 \cdot 283 \mathrm{~V}$. No relation was seen between maximum hyperaemic response and ambient blood glucose concentration, systolic pressure taken at the ankle, or systolic, diastolic, or mean brachial artery pressure.

\section{Comment}

The microvascular hyperaemic response to thermal injury is impaired at diagnosis in patients with noninsulin dependent diabetes, although how long they have had the disease is unknown. The impairment is considerable even compared with insulin dependent patients with moderate duration of diabetes (median 19 years), and the relation to the duration of diabetes is unlikely to provide the whole explanation. ${ }^{2}$ Increased peripheral resistance may occur in the non-insulin dependent subjects during the non-diabetic but hyperinsulinaemic, insulin resistant phase before pancreatic exhaustion.

The microvascular mechanisms underlying the impairment may differ in the two types of diabetes, resistance occurring higher in the arteriolar tree, where it would contribute more to peripheral resistance. ${ }^{+}$ Such a concept would be in keeping with contemporary reasoning linking insulin resistance and hypertension. ${ }^{5}$

The mechanism underlying the development of impaired maximum hyperaemic response in newly diagnosed non-insulin dependent diabetic patients requires elucidation. The impairment in vasodilatory reserve may possibly contribute to foot ulceration.

This study was made possible by the support for the United Kingdom prospective diabetes study from the Medical Research Council, Bristol Myers Squibb, and Farmitalia Carlo Erba.

1 West KM. Epidemiology of diabetes and its vascular lesions. New York: Elsevier North Holland, 1978:353-401.

2 Rayman (i, Williams SA, Spencer PD, Smaje LH, Wise PH, Tooke JE. Impaired microvascular hyperaemic response to minor skin trauma in type I Impaired microvascular hyperaen

3 O'Hare JA. The enigma of insulin resistance and hypertension. Am J Med 1988;84:505-10.

4 Wiedeman M, Tumar R, Mayrovitz H. Defining the precapillary sphincter. Microvasc Res 1976;12:71-5.

5 Reaven GM, Hoffman BB. Hypertension as a disease of carbohydrate and lipoprotein metabolism. Am f Med 1989;87 (suppl 6A):6-25.

(Accepled 12. March 1991)

\section{ONE HUNDRED YEARS AGO}

The proposal to establish ambulance classes for the mercantile marine appears to be one in every way well worthy of support. The great ocean-going steamers belonging to the passenger lines carry surgeons; but ordinary cargo boats, whether "ocean tramps" or sailing ships, do not; when accidents occur, or when sickness breaks out on board such boats, the captain or some other officer consults the book of instructions, which is supposed to be found in company with the ship's medicine chest, and many are the yarns told as to the peculiarities of the consequent practice. If these officers, who are generally men of considerable intelligence and mother-wit, could find at the chief ports classes specially arranged to meet their convenience and needs, they would probably take advantage of them to pick up a few useful hints. Such knowledge would be of great use to them if called upon to treat burns or scalds, to reanimate the apparently drowned or partially suffocated, or to arrest haemorrhage. As to fractures, it should be quite possible to teach the sailor, with his well-known handiness, how to deal with all fractures so as to diminish pain, and with many simple fractures so as to produce a fairly satisfactory cure. At Liverpool, the meeting of shipowners which decided that ambulance courses ought to be established, adopted a resolution which went a good deal further: "To establish ambulance classes specially adapted for sea service, and include in the course of lectures the important subjects of ship sanitation and personal hygiene." As we have frequently pointed out, there is great room for improvement in sanitation, not only in "ocean tramps," but in ocean liners otherwise well appointed. (British Medical fournal 1891;i:538) 